\title{
Detection of HTLV-Ila in blood donors in an urban area of the Amazon Region of Brazil (Belém, PA)
}

\author{
Detecção de HTLV-Ila em doadores de sangue em uma área urbana \\ da Amazônia Brasileira (Belém, PA)
}

\author{
R. Ishak, M.O.G. Ishak, V.N. Azevedo, D.E.M. Santos, A.C.R. Vallinoto, \\ J.C.P. Saraiva, J.A. Crescente and W.W. Hall.
}

\begin{abstract}
The human lymphotropic viruses type I (HTLV-I) and type II (HTLV-II) are members of a group of mammalian retroviruses with similar biological properties, and blood transfusion is an important route of transmission. HTLV-I is endemic in a number of different geographical areas and is associated with several clinical disorders. HTLV-II is endemic in several Indian groups of the Americas and intravenous drug abusers in North and South America, Europe and Southeast Asia. During the year of 1995, all blood donors tested positive to HTLV-I/II in the State Blood Bank (HEMOPA), were directed to a physician and to the Virus Laboratory at the Universidade Federal do Pará for counselling and laboratory diagnosis confirmation. Thirty-five sera were tested by an enzyme immune assay, and a Western blot that discriminates HTLV-I and HTLV-II infection. Two HTLV-II positive samples were submitted to PCR analysis of $p X$ and env genomic region, and confirmed to be of subtype Ila. This is the first detection in Belém of the presence of HTLV-Ila infection among blood donors. This result emphasizes that HTLV-II is also present in urban areas of the Amazon region of Brazil and highlights the need to include screening tests that are capable to detect antibodies for both types of HTLV.
\end{abstract}

Key-words: HTLV-II. Retrovirus. Blood donors. Blood.

Resumo Os vírus linfotrópicos de células Thumanas tipo I (HTLV-I) e tipo II (HTLV-II) são membros de um grupo de retrovírus de mamíferos com propriedades biológicas similares que apresentam como uma das principais rotas de transmissão a transfusão sangüínea. O HTLV-I é endêmico em diferentes áreas geográficas e está associado a vários distúrbios clínicos. O HTLV-II é endêmico em vários grupos indígenas das Américas e em usuários de drogas intravenosas na América do Norte e do Sul, Europa e Sudeste da Ásia. Durante o ano de 1995, todos os doadores de sangue positivos para HTLV-I/II no Banco de Sangue do Estado (HEMOPA), foram direcionados a um médico e ao Laboratório de Virologia na Universidade Federal do Pará, para consulta, aconselhamento e confirmação do diagnóstico laboratorial. Trinta e cinco soros foram testados por um ensaio imunoenzimático e confirmados por um Western blot que discrimina as infecções por HTLV-I e HTLVII. Amostras soropositivas para HTLV-II foram submetidas à reação em cadeia da polimerase (PCR) para as regiões genômicas env e $\mathrm{pX}$ e confirmaram ser do subtipo lla. Esta é a primeira detecção, em Belém, da presença da infecção pelo HTLV-Ila em doadores de sangue. Estes resultados enfatizam que o HTLV-Il está presente em áreas urbanas da região Amazônica e a necessidade de incluir testes de triagem capazes de detectar anticorpos para ambos os tipos de HTLV.

Palavras-chaves: HTLV-II. Retrovirus. Doadores de sangue. Sangue.

Laboratório de Virologia da Universidade Federal do Pará, Belém, PA. Núcleo de Medicina Tropical do Pará. Centro de Hematologia e Hemoterapia do Pará (HEMOPA) and University College, Dublin, Irlanda.

Address to: Dr. Ricardo Ishak. Caixa Postal 13005, 66040-970 Belém, PA.

Fax: (091) 212-2468

Recebido para publicação em 08/07/97. 
The closely related T-cell lymphotropic virus types I and II (HTLV-I and HTLV-II) are members of a group of mammalian retroviruses which have similar biological properties 45 .

HTLV-I has been showed to be endemic in several geographical areas, including Africa, Europe, Southeast Asia, Japan, the Caribbean, North and South America5 10, where the infection is associated with adult T-cell leukemia (ATL), a neurological disorder known as HTLV-associated myelophaty (HAM) or tropical spastic paraparesis (TSP), and a characteristic uveitis5.

HTLV-II infection, which appears to be less pathogenic than HTLV-I, is endemic in several Indian communities from the Americas2 5679 and among intravenous drug abusers (IVDA) and blood donors in North and South America and Europe 5810.

Blood transfusion is an important route for HTLV-II transmission, therefore screening of blood donors is crucial to prevent further dissemination of the virus. In Brazil, blood screening for HTLV is mandatory but in general, no further investigation is carried out.

The present paper shows the detection of HTLV-Ila for the first time in an urban area of the Amazon Region of Brazil using serological methods and the PCR.

\section{MATERIAL AND METHODS}

Population examined and samples. During the year of 1995, blood donors who tested positive in the screening test at the State Blood Bank (HEMOPA) and two patients with hematological disorders, took part in a collaborative study and were directed to a physician and to the Virus Laboratory of the Universidade Federal do Pará (UFPA) for counselling and laboratory diagnostic confirmation. Thirty-five subjects (31 men and 4 women aged 11 to 58 years old) were examined. Blood samples were collected and placed in tubes without anticoagulants to obtain serum, and in tubes containing HESPAN (Du Pont, USA) in order to separate peripheral blood mononuclear cells (PBMC). Both samples were maintained at $-20^{\circ} \mathrm{C}$ before use.

Serological assay. Serum samples were assayed for the presence of antibodies to HTLV$\mathrm{I} / \mathrm{Il}$ by an enzyme immunoassay (EIA, Coulter Corporation, USA) and the positive samples were tested by a Western blot (Cambridge Biotech, USA) capable of distinguishing HTLV-I from HTLV-II. Positive and discriminatory criteria followed the manufacturer recommendations and considered reactions to p24, p19 and rgp21. HTLV-I positive sera reacted stronger to p19 than to p24. HTLV-II positivity showed a stronger reaction to p24 and could be absent to p19.

Polymerase chain reaction (PCR). DNA extraction was performed on PBMC from HTLVII seropositive blood donors. The extracted product was used for the detection of the provirus genome using a nested PCR to amplify the $p x$ region.

The first PCR was carried out using $1 \mu \mathrm{g}$ of the extracted DNA, $125 \mu \mathrm{M}$ of each dNTP (PerkinElmer, USA), $20 \mathrm{pmol} / \mu \mathrm{L}$ of each of the two external primers and 10x PCR buffer $-\mathrm{MgCl}_{2}$ (Perkin-Elmer, USA), ending up with a final volume of $50 \mu \mathrm{L}$. The reaction was incubated in a termocycler (Perkin-Elmer, USA) for five minutes at $94^{\circ} \mathrm{C}$, followed by 35 cycles at $94^{\circ} \mathrm{C}(40$ seconds), $51.6^{\circ} \mathrm{C}$ (30 seconds), $72^{\circ} \mathrm{C} \quad(40$ seconds) and extended for 10 minutes at $72^{\circ} \mathrm{C}$.

Five microliters of the amplified product were taken for the nested PCR using a different set of internal primers, however maintaining the same mixture (with a final volume of $100 \mu \mathrm{L}$ ), temperature and incubation periods of the first reaction. The external primers sequences were 5'-TTCCCAGGGTTTGGACAGAG3' (nucleotides 7308-7327) and 5'GGGTAAGGACCTTGAGGGTC-3' (nucleotides 7572-7553). The internal primers sequences were 5'-CGGATACCCAGTCTACGTGTT-3' (nucleotides 7337-7357) and 5'GAGCCGATAACGCGTCCATCG-3' (nucleotides 7495-7475). The two amplified products were detected after an electrophoresis in a $2 \%$ agarose gel (200V, $120 \mathrm{Amp} / 45 \mathrm{~min}$ ), revealed by staining with ethidium bromide and visualized under an UV light.

The restriction fragment length polymorphism (RFLP) typing of this product (159 bp for both HTLV-I and HTLV-II) is performed by mixing it $(10 \mu \mathrm{L})$ with $0.4 \mu \mathrm{L}$ of the restriction endonuclease enzyme Taq I and incubating at $65^{\circ} \mathrm{C}$ for at least 5 hours. The restriction site for the enzyme (T/CGA) is present in HTLV-II, generating two bands ( $85 \mathrm{bp}$ and $53 \mathrm{bp}$ ) following an electrophoresis in a $3 \%$ agarose gel. HTLV-I lacks this particular site and runs as a single band.

The subtyping of HTLV-II was obtained using a nested PCR, with two sets of primers that match a conservative nucleotide sequence 
flanking the env region, and coding for the envelope protein, as described previously 3 . The PCR product (631 bp) was enzymatically digested by Xho I. The RFLP pattern obtained discriminates between HTLV-Ila and HTLV-IIb subtypes by the presence of the C/TCGAG site in the HTLV-Ila, that is evidenced by the presence of two fragments (179 and $452 \mathrm{bp}$ ) on a $3 \%$ agarose gel electrophoresis.

\section{RESULTS}

Serology. Positivity to HTLV-I/II in thirty-five subjects tested is shown in Table 1. Serological diagnostic evidence of HTLV infection was confirmed in 15 subjects. Antibodies against HTLV-I were found in 10 (28.6\%) subjects (eight males and two females), and three others showed an indeterminate pattern reaction $(8.6 \%)$. Additionally, two blood donors $(5.7 \%)$, one male and one female, were characterized as having an HTLV-II infection.

$P C R$ assay. The amplification of the $p X$ genomic region, followed by enzymatic digestion, showed in both samples the restriction site to Taq I endonuclease confirming that they were both HTLV-II. The amplification of env and the subsequent RFLP pattern revealed the migration of two bands indicating that both samples were

Table 1 - Distribution of blood donors according to age, sex and HTLV infection (Western blot).

\begin{tabular}{|c|c|c|c|c|}
\hline Case & Age & Sex & Result & $\%$ \\
\hline 1 & 28 & $M$ & $\mathrm{Neg}$ & - \\
\hline 2 & 38 & $M$ & $\mathrm{Neg}$ & - \\
\hline 3 & 41 & $M$ & $\mathrm{Neg}$ & - \\
\hline 4 & 43 & $M$ & Neg & - \\
\hline 5 & 44 & $M$ & $\mathrm{Neg}$ & - \\
\hline 6 & 19 & $M$ & $\mathrm{Neg}$ & - \\
\hline 7 & 30 & $M$ & $\mathrm{Neg}$ & - \\
\hline 8 & 24 & $M$ & $\mathrm{Neg}$ & - \\
\hline 9 & 41 & $\mathrm{~F}$ & $\mathrm{Neg}$ & - \\
\hline 10 & 23 & $M$ & $\mathrm{Neg}$ & - \\
\hline 11 & 25 & $M$ & $\mathrm{Neg}$ & - \\
\hline 12 & 30 & $M$ & $\mathrm{Neg}$ & - \\
\hline 13 & 31 & $M$ & $\mathrm{Neg}$ & - \\
\hline 14 & 51 & $M$ & $\mathrm{Neg}$ & - \\
\hline 15 & 34 & $M$ & $\mathrm{Neg}$ & - \\
\hline 16 & 40 & $M$ & $\mathrm{Neg}$ & - \\
\hline 17 & 18 & $M$ & $\mathrm{Neg}$ & - \\
\hline 18 & 25 & $M$ & $\mathrm{Neg}$ & - \\
\hline 19 & 35 & $M$ & $\mathrm{Neg}$ & - \\
\hline 20 & 30 & $M$ & $\mathrm{Neg}$ & 57.1 \\
\hline 21 & 11 & $M$ & HTLV-I & - \\
\hline 22 & 34 & $M$ & HTLV-I & - \\
\hline 23 & 41 & $M$ & HTLV-I & - \\
\hline 24 & 43 & $M$ & HTLV-I & - \\
\hline 25 & 44 & $M$ & HTLV-I & - \\
\hline 26 & 44 & $M$ & HTLV-I & - \\
\hline 27 & 44 & $M$ & HTLV-I & - \\
\hline 28 & 58 & $M$ & HTLV-I & - \\
\hline 29 & 15 & $\mathrm{~F}$ & HTLV-I & - \\
\hline 30 & 34 & $\mathrm{~F}$ & HTLV-I & 28.6 \\
\hline 31 & 32 & $M$ & HTLV-II & - \\
\hline 32 & 30 & $\mathrm{~F}$ & HTLV-II & 5.7 \\
\hline 33 & 24 & $M$ & Ind & - \\
\hline 34 & 25 & $M$ & Ind & - \\
\hline 35 & 26 & $M$ & Ind & 8.6 \\
\hline
\end{tabular}

Neg = negative; Ind = indeterminated. 
HTLV-II, subtype a.

\section{DISCUSSION}

Samples of blood donors and patients with hematological disorders from the State Blood Bank (HEMOPA) from Belém, Pará, Brazil, were examined by serological and molecular methods in order to identify and characterize HTLV-I/II infections. The frequency of antibodies confirmed a higher infection rate of HTLV-I in the group examined, a common pattern seen both in Brazil and elsewhere 111 . The majority of the blood donors did not refer a previous history of blood transfusion and with the exception of two adolescents (\#21 and \#29) who were seen at the time for treatment of hematological disorders, all the others may represent cases of sexual transmission of HTLV-I/II (although it could not be ruled out the possibility of vertical transmission). The clear predominance of males reflects the imbalance of gender among blood donors in Belém, and it can not be taken into consideration as a significant difference of HTLV incidence.

The molecular characterization of the HTLVII infecting two blood donors after the amplification of env followed by enzymatic digestion, showed that both were HTLV-II, subtype a. This subtype is the most frequently found (83\%) among blood donors in the USA10 and indeed, it is the same subtype commonly found among native Indians of the Amazon Region of Brazil and drug addicts from São Paulo, Brazil3 7. It was not possible to epidemiologically link the two blood donors to any risk factor including blood transfusion, drug addiction or sexual promiscuity. Furthermore, none referred previous contact with native Indians. This result, however, enlarges the geographical limits of the endemic area for HTLV-II in the Amazon Region of Brazil. It is the first time the virus is detected in an urban setting of this region.

Although we are still in an initial process of epidemiological and molecular characterization of HTLV-II from urban areas of the Amazon Region of Brazil, the preliminary results highlight the importance to determine which virus was transmitted and is present in the recipient. The distinction between HTLV-I and HTLV-II, shows a crucial prognostic significance to the infected person. This is an important criteria for medical counselling and emphasizes the need to include screening tests that are capable to detect both types of HTLV in blood bank screening.

\section{ACKNOWLEDGMENTS}

The present work was partially supported by grants from the Universidade Federal do Pará and Conselho Nacional de Desenvolvimento Científico e Tecnológico-CNPq.

\section{REFERENCES}

1. Boletim Epidemiológico. Distribuição geográfica diferencial do HTLV-I/II no Brasil. PN-DST/AIDS. Brasilia, p. 2, 1995.

2. Duenas-Barrajas E, Bernal JE, Vaught DR, Nerurkar VR, Sarmiento P, Yanagihara R, Gaidjusek DC. Human retroviruses in Amerindians of Colombia: High prevalence of human T cell lymphotropic virus type II infection among the Tunebo Indians. American Journal of Tropical Medicine and Hygiene 46:657663, 1993.

3. Eiraku N, Novoa P, Costa Ferreira M, Monken C, Ishak R, Costa Ferreira O, Zhu SW, Lorenco R, Ishak MOG, Azevedo VN, Guerreiro JF, Pombo de Oliveira M, Loureiro P, Hammerschlak N, ljichi S, Hall WW. Identification and characterization of new and distinct molecular subtype of Human T-Cell Lymphotropic Virus Type II. Journal of Virology 70:1481-1492, 1996.

4. Hall WW, Takahashi H, Liu C, Kaplan MH, Scheewind O, ljichi S, Nagashima K, Gallo RC. Multiple isolates and characteristics of human T-cell leukemia virus type II. Journal of Virology 66:2456-2463, 1992.

5. Hall WW, Ishak R, Zhu SW, Novoa P, Eiraku N, Takahashi H, Costa Ferreira M, Azevedo VN, Ishak MOG, Costa Ferreira O, Monken C, Kurata T. Human T Lymphotropic Virus Type II (HTLV-II): Epidemiology, Molecular Properties, and Clinical Features of Infection. Journal of Acquired Immune Deficiency Syndromes and Human Retrovirology 13 (suppl 1): S204-S214, 1996.

6. Hjelle B, Zhu SW, Takahashi H, ljichi S, Hall WW. Endemic human $T$ cell leukemia virus type II infection in southwestern US Indians involves two subtypes variants of virus. Journal of Infectious Disease 168:738-740, 1993.

7. Ishak R, Harrington Jr WJ, Azevedo VN, Eiraku N, Ishak MGO, Guerreiro JF, Santos SEB, Kubo T, Monken C, Alexander S, Hall WW. Identification of T Cell Lymphotropic Virus Type Ila in the Kayapo, an indigenous population of Brazil. AIDS Research and Human Retroviruses 11:813-821, 1995.

8. Lee HH, Swanson P, Rosenblatt J, Chen ISY, 
Sherwood WC, Smith D, Tegtmeier GE, Fernando LP, Fang CT, Osame M, Kleinman SH. Relative prevalence and risk factors of HTLV-I and HTLV-II infection in US blood donors. Lancet 337:1435-1439, 1991.

9. Levine $\mathrm{PH}$, Jacobson $\mathrm{S}$, Elliott $\mathrm{R}$, Cavallero $\mathrm{A}$, Colclough G, Dorry C, Stephenson C, Knnigge RM, Drummond J, Nishimura M, Taylor ME, Wiktor S, Shaw GM. HTLV-II infection in Florida Indians. AIDS Research Human Retroviruses 9:123-127, 1993.
10. Switzer WM, Pieniazek D, Swanson P, Samdal HH, Soriano V, Khabbaz RF, Kaplan JE, Lal RB, Heneine W. Phylogenetic Relationship and Geographic Distribution of multiple Human T-Cell Lymphotropic Virus Type II subtypes. Journal of Virology 69:621-632, 1995.

11. Taylor GP. The epidemiology of HTLV-I in Europe. Journal of Acquired Immune Deficiency Syndromes and Human Retrovirology 13(suppl 1):S8-S14, 1996. 